\title{
THE EARLY WARNING MODEL OF TRACK AND FIELD SPORTS BASED ON RBF NEURAL NETWORK ALGORITHM
}

\author{
OMODELODE ALERTA PRECOCE DE ESPORTES DE PISTA E CAMPO BASEADO NO ALGORITMO DE REDE \\ NEURALRBF
}
EL MODELO DE ALERTA TEMPRANA DE LOS DEPORTES DE PISTA Y CAMPO BASADO EN EL ALGORITMO DE REDNEURONAL RBF

\author{
Hegiong Wen ${ }^{1}$ (iD \\ (Physical Education Professional) \\ 1. Sport College, Qujing normal \\ University, Qujing, China.
}

\section{Correspondence:}

Heqiong Wen. Sport College,

Qujing normal University,

Qujing 655000, China.

wenheqiong363@126.com

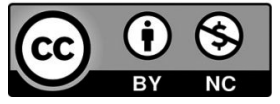

\begin{abstract}
Background: Athletics plays a very important role in competitive sports. The strength of track and field directly represents the level of a country's sports competition. Objective: This work aimed to study the track and field sports forewarning model based on radial basis function (RBF) neural networks. One hundred outstanding athletes were taken as the research objects. The questionnaire survey method was adopted to count athletes' injury risk factors, and coaches were consulted to evaluate the questionnaire's overall quality, structure, and content. Methods: A track and field early warning model based on RBF neural network is established, and the results are analyzed. Results: The results showed that the number of people who thought the questionnaire was relatively complete (92\%) was considerably higher than that of very complete (2\%) and relatively complete $(6 \%)(P<0.05)$. The number of people who thought that the questionnaire structure was relatively perfect $(45 \%)$ was notably higher than that of the very perfect $(18 \%)(P<0.05)$. The semi-reliability test result suggested that the questionnaire reliability was 0.85 . Tests on ten samples showed that the RBF neural network model error and the actual results were basically controlled between -0.04 0.04. Conclusions: After the sample library test, the track and field sports forewarning model under RBF neural network can obtain relatively favorable results. Level of evidence Il; Therapeutic studies - investigation of treatment results.
\end{abstract}

Keywords: Track and field; Wound and injuries; Forewarning model.

\section{RESUMO}

Antecedentes: $O$ atletismo desempenha um papel muito importante nos esportes competitivos. A força do atletismo representa diretamente o nível de competição esportiva de um país. Objetivo: Este trabalho teve como objetivo estudar o modelo de advertência em esportes de atletismo baseado em redes neurais de função de base radial (RBF). 100 atletas de destaque foram tomados como objetos de pesquisa. O método de pesquisa por questionário foi adotado para contar os fatores de risco de lesões dos atletas e os treinadores foram consultados para avaliar a qualidade geral, estrutura e conteúdo do questionário. Métodos: Um modelo de alerta precoce de pista e campo baseado na rede neural RBFéestabelecido e os resultados são analisados. Resultados: Os resultados mostraram que o número de pessoas que consideraram o questionário relativamente completo (92\%) foi consideravelmente maior do que o de muito completo (2\%) e relativamente completo (6\%) $(P<0,05)$. O número de pessoas que pensaram que a estrutura do questionário era relativamente perfeita (45\%) foi notavelmente maior do que a das muito perfeitas (18\%) ( $P<0,05)$. O resultado do teste de semifiabilidade sugeriu que a confiabilidade do questionário foi de 0,85. Testes em 10 amostras mostraram que o erro entre o modelo de rede neural RBF e os resultados reais foi basicamente controlado entre-0,04 0,04. Conclusões: Após o teste da biblioteca de amostras, o modelo de advertência em esportes de atletismo sob a rede neural RBF pode obter resultados relativamente favoráveis. Nível de evidência ll; Estudos terapêuticos- investigação dos resultados do tratamento.

Descritores: Atletismo; Ferimentos elesões; Modelo de advertência.

\section{RESUMEN}

Antecedentes: el atletismo juega un papel muy importante en los deportes competitivos. La fuerza de la pista y el campo representa directamente el nivel de competición deportiva de un país. Objetivo: Este trabajo tuvo como objetivo estudiar el modelo de alerta de los deportes de pista y campo basado en redes neuronales de función de base radial (RBF). Se tomaron como objeto de investigación 100 atletas destacados. Se adoptó el método de encuesta de cuestionario para contar los factores de riesgo de lesiones de los atletas y se consultó a los entrenadores para evaluar la calidad general, la estructura y el contenido del cuestionario. Métodos: Se establece un modelo de alerta temprana de pista y campo basado en la red neuronal RBF y se analizan los resultados. Resultados: Los resultados mostraron que el número de personas que pensaban que el cuestionario era relativamente completo (92\%) era considerablemente mayor que el de muy completo $(2 \%)$ y relativamente completo $(6 \%)(P<0,05)$. El número de personas que pensaba que la estructura del cuestionario era relativamente perfecta (45\%) fue notablemente superior al de los muy perfectos (18\%) ( $P<0,05)$. El resultado de la prueba de semifiabilidad sugirió que la confiabilidad del cuestionario era 
0,85. Las pruebas en 10 muestras mostraron que el error entre el modelo de red neuronal RBF y los resultados reales se controló básicamente entre-0,04 0,04. Conclusiones: Después de la prueba de la biblioteca de muestras, el modelo de advertencia de deportes de pista y campo bajo la red neuronal RBF puede obtener resultados relativamente favorables.

\section{Nivel de evidencia Il; Estudios terapéuticos- investigación de los resultados del tratamiento.}

Descriptores: Atletismo; Heridas y lesiones; Modelo de advertencia.

\section{INTRODUCTION}

Track and field is the full name of track and field, track and field, all-around competition, mainly including walking, running, jumping and other events, ${ }^{1,2}$ a total of more than 40 kinds. A lot of athletes missed the trophy because they were injured in track and field. ${ }^{3}$ Therefore, it is urgent to establish a track and field early warning model.

Radial basis function (RBF) neural network has a simple structure, which can use nonlinear function to improve, 4,5 learning efficiency. RBF neural networks are widely adopted in image processing, data analysis, information processing, and system modeling. ${ }^{6,7}$ Zaremski et al. (2019) ${ }^{8}$ explained the interaction between various risk factors and the correlation with sports injuries by constructing a dynamic chain model.

The RBF neural network algorithm can solve this type of problem well. The data in the sample database was information about the risk factors related to the athlete's injury warning and the corresponding warning level. ${ }^{9-11}$ The quality of the data in the sample library directly affected the training results of the data in the sample library. ${ }^{12,13}$

In this research, based on RBF neural network, the forewarning model for track and field sportsmen was built. By collecting basic data on injury-causing factors related to sports injuries, quantitative assessment of early warning levels was made. Then, combined with the early warning evaluation results of the athlete coaches, the results of the early warning levels were comprehensively evaluated, to provide data supplements for the sample database.

\section{RESEARCH METHODS}

\section{Research object and quantitative assignment}

In this research,100 track and field athletes from $X$ province were studied. By sorting out the results of the questionnaire, the risk factors of sports injury were classified and quantitatively distributed. Select 20 coaches to conduct a risk rating questionnaire.

Quantitative evaluation criteria were as follows. 0 points, the risk factor didn't cause athletes injury. 1 point, this factor had the smallest contribution to the risk of sports injury. 2 points, this factor had caused sports injuries. 3 points, once this factor appeared, it would cause athletes injury. The research had been approved by the sports department of $X$ province. The athletes and their family members understood the research and signed the informed consent forms.

\section{Research on risk factors of sports injury}

The dynamic chain model established by this study: internal damage factors (10), external damage factors (5 types) and induced stimulating factors (5). When the internal injury factors appear, the track and field athletes are athletes who have injured tendencies. Therefore, it is necessary to evaluate the risk of harm in time and perform an early warning. This study evaluated the risk factors of 100 athletes, randomly selected six athletes to quantify.

\section{Risk classification and comprehensive assessment method}

The risk coefficient of each damage factor is obtained by quantitative distribution method. Through statistics, the average value of the upper and lower standard deviations is set to the medium risk level according to the calculation results. Above the standard deviation is the high risk grade, below the standard deviation is the low risk grade.

A questionnaire survey of coaches and experts is needed. When the risk level assessed by the coach exceeds 85, the coach's opinion shall prevail. When the risk level of coach evaluation is less than 85 , the linear model evaluation results shall prevail.

\section{Establishment of RBF neural network}

In this research, the RBF neural network was employed to input the information of track and field sports players' sports injury factors. The warning level was classified into low, medium, and high. The output corresponding value of the risk level in the RBF neural network was shown in Table 1.

A classifier was built via the RBF neural network. The activation function of the hidden unit adopted the Gaussian function, and the expression was as follows.

$$
G_{i}(x)=e^{-\frac{\left\|x-b_{i}\right\|^{2}}{2 \omega_{i}^{2}}}
$$

In equation (1), $G_{i}(x)$ represents the output value of the $i$-th hidden unit, $x$ represents the $n$-th variable output in the network, $b_{i}$ represents the central vector of the kernel function in the $i$-th hidden unit, and then the network output is defined as follows.

$$
y_{i}=\sum_{i=1}^{l} \xi_{i j} G_{i}(x)
$$

In equation (2), $j=1,2, \cdots, m$ is satisfied. $y_{i}$ represents the output value of the unit in the $i$-th output layer, and $\xi_{i j}$ represents the connection weight from the $i$-th hidden unit to the $j$-th output unit. Through learning of the radial basis function, the relative error method is adopted to correct the learning process and gradually integrated into the gradient descent method. The calculation process is as follows.

Assuming there are $M$ sample size, the error function of the input sample is defined as follows.

$$
\lambda=\frac{1}{2} \sum_{p=1}^{M} e_{p}^{2}
$$

Table 1. Corresponding output value of risk level in RBF neural network.

\begin{tabular}{c|c}
\hline Sports injury warning risk level & $\begin{array}{c}\text { RBF neural network output } \\
\text { corresponding value }\end{array}$ \\
\hline High risk & 3 \\
\hline Medium risk & 2 \\
\hline Low risk & 1 \\
\hline
\end{tabular}


In equation (3), $e_{p}^{2}$ represents the error and $\lambda$ represents the error function. The definition equation of error is as follows.

$$
e_{p}=b_{p}-y\left(x_{p}\right)=b_{p}-\sum_{i=1}^{3} \xi_{1 i} e^{-\frac{\left\|x-b_{i}\right\|^{2}}{2 \omega_{i}^{2}}}
$$

In equation (4), $b_{p}$ represents the corresponding value of $x_{p}$ in the sample. For example, in this study, the low-risk level sample corresponds to $b_{p}=1$, and the high-risk level sample $b_{p}=3$.

According to the combination of the RBF neural network training process and the extracted early warning sample library of athletes'injury factors, the RBF neural network training process was shown in Figure 1.

\section{Statistical methods}

IBM SPSS Statistics 19.0 software was employed for statistical analysis of data. The calculated data that didn't meet the normal distribution were

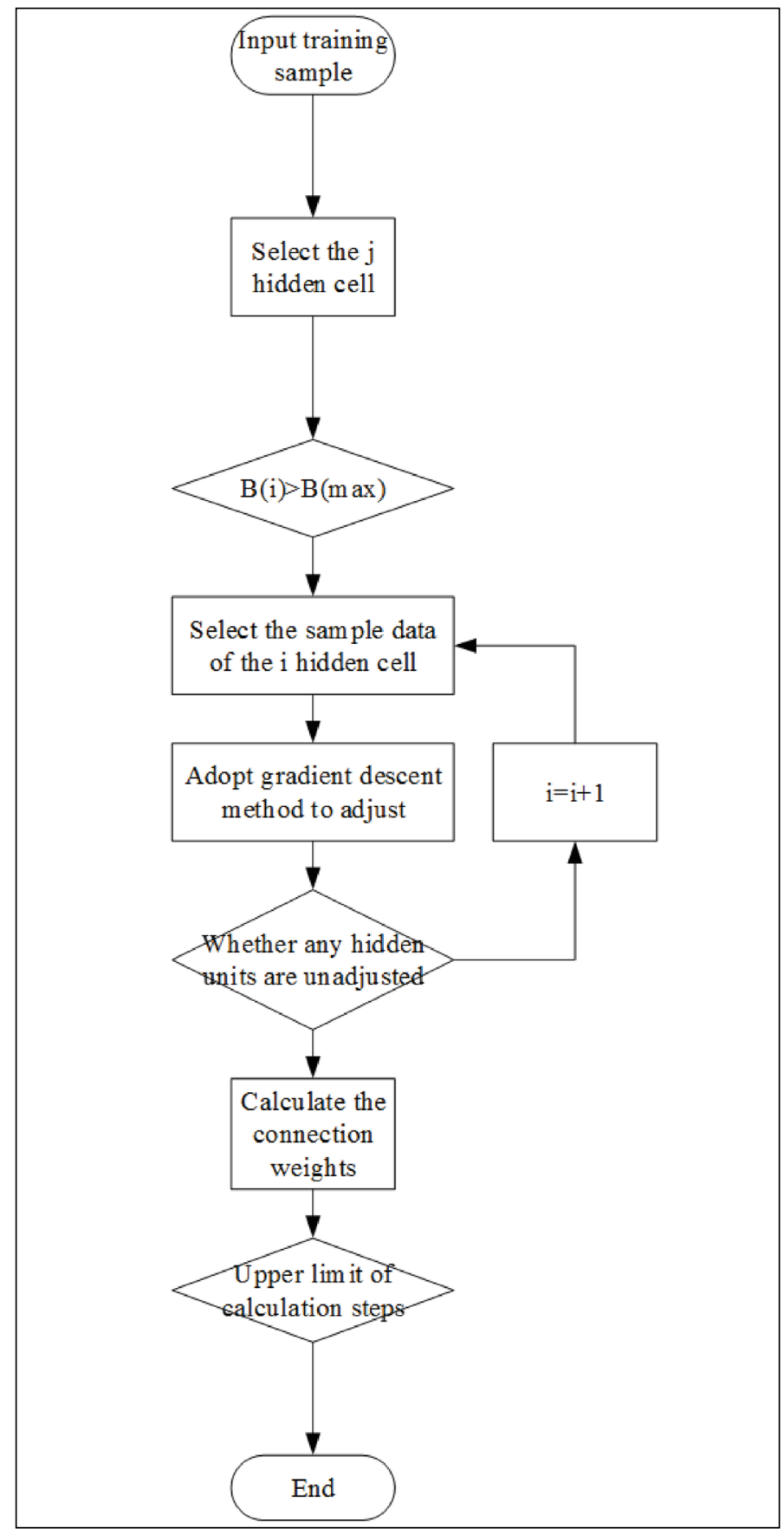

Figure 1. RBF neural network flow chart. expressed by frequency and percentage. The analytic hierarchy process was implemented to get the coefficient of risk factor. The validity test method was adopted to analyze and evaluate the overall structure of the questionnaire. The difference was statistically considerable with $P<0.05$.

\section{RESULTS}

\section{Statistical results of injury factors of sports injuries}

See Table 2 for the internal damage factors. See external damage factors in Table 3 and Table 4 for induced stimulation factors .Among them, the difficulty of sports level, the number of replacement sneakers , subjective fatigue state are several risk factors leading to sports injury .

\section{Coaches' questionnaire results}

A questionnaire survey was conducted on coaches engaged in track and field sports. Test papers were distributed to 20 coaches, and 18 copies were recovered, with a recovery rate of $90 \%$. The specific situation of the coach was shown in Figure 2. There were 8 general coaches, 6 senior coaches, and 4 national coaches.

The statistical results were shown in Figure 3. The "not perfect" and "imperfect" in each evaluation were all 0. For overall quality evaluation, 92\% thought that the questionnaire was relatively perfect as a whole, which was notably higher than very perfect (2\%) and comparatively perfect (6\%), and the difference was substantial $(P<0.05)$. For structure evaluation, the number of people who thought that the questionnaire structure was relatively perfect accounted for 45\%, which was significantly higher than that of very perfect (18\%), and the difference was significant $(P<0.05)$. For content evaluation, the number of people who thought that the questionnaire content was relatively perfect accounted for $69 \%$, which was significantly superior to that of very perfect (10\%) and comparatively perfect (21\%), with notable differences $(P<0.05)$.

Table 2. Statistics of internal factors for track and field sports players.

\begin{tabular}{c|l|l|l|l|l|l}
\hline Athlete number & $\mathbf{1}$ & $\mathbf{2}$ & $\mathbf{3}$ & $\mathbf{4}$ & $\mathbf{5}$ & $\mathbf{6}$ \\
\hline Age & 2 & 3 & 2 & 3 & 2 & 2 \\
\hline Sport level & 3 & 2 & 2 & 3 & 3 & 3 \\
\hline BMl & 1 & 2 & 2 & 2 & 2 & 1 \\
\hline Joint stability & 2 & 2 & 2 & 2 & 2 & 2 \\
\hline Joint flexibility & 2 & 2 & 3 & 2 & 3 & 2 \\
\hline Injury history & 1 & 2 & 0 & 1 & 2 & 1 \\
\hline Damage recovery & 2 & 2 & 1 & 2 & 1 & 1 \\
\hline Body balance & 2 & 2 & 2 & 3 & 2 & 2 \\
\hline Thigh muscle group strength comparison & 1 & 1 & 1 & 2 & 1 & 1 \\
\hline Arch state & 2 & 1 & 1 & 1 & 2 & 1 \\
\hline & & & &
\end{tabular}

Table 3. Statistics of external injury factors for track and field sports players.

\begin{tabular}{c|l|l|l|l|l|l}
\hline Athlete number & $\mathbf{1}$ & $\mathbf{2}$ & $\mathbf{3}$ & $\mathbf{4}$ & $\mathbf{5}$ & $\mathbf{6}$ \\
\hline Sports shoes replacement times & 3 & 3 & 3 & 3 & 2 & 3 \\
\hline Application of protection measures & 2 & 2 & 3 & 1 & 1 & 3 \\
\hline Technique level & 2 & 2 & 2 & 3 & 2 & 3 \\
\hline Weather factor & 2 & 2 & 2 & 2 & 2 & 2 \\
\hline Site factor & 2 & 1 & 1 & 2 & 1 & 1 \\
\hline
\end{tabular}

Table 4. Statistics of inducing stimulus factors for track and field sports players.

\begin{tabular}{c|c|c|c|c|c|c}
\hline Athlete number & $\mathbf{1}$ & $\mathbf{2}$ & $\mathbf{3}$ & $\mathbf{4}$ & $\mathbf{5}$ & $\mathbf{6}$ \\
\hline Athlete fatigue & 3 & 3 & 3 & 3 & 3 & 3 \\
\hline Body function & 1 & 2 & 1 & 1 & 2 & 2 \\
\hline Training load & 2 & 3 & 2 & 2 & 3 & 2 \\
\hline Mental quality & 1 & 1 & 2 & 1 & 1 & 2 \\
\hline Technical action specifications & 1 & 1 & 1 & 1 & 1 & 1 \\
\hline
\end{tabular}




\section{Analysis of the results of track and field sports forewarning model}

Early warning model results are compared with actual results in Table 5.

According to the experimental results, the test verification of 10 test samples showed a good effect, and the error was basically controlled between -0.04-0.04.

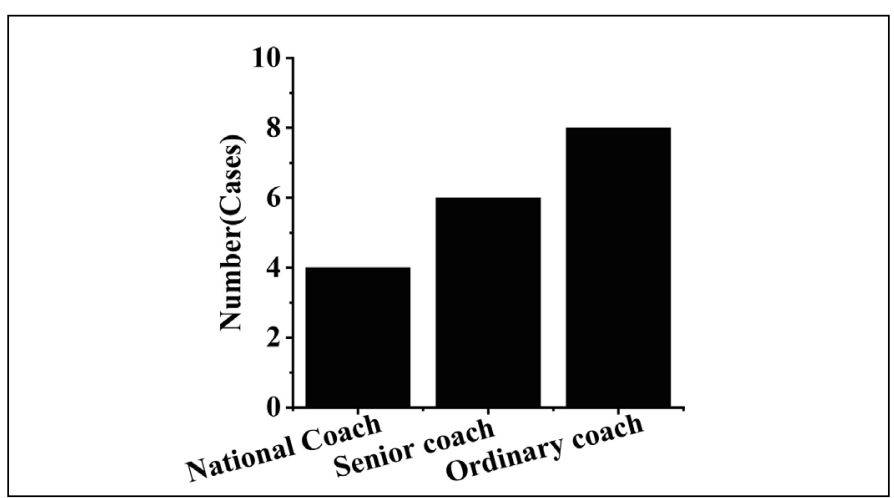

Figure 2. Statistics of the number of coaches.

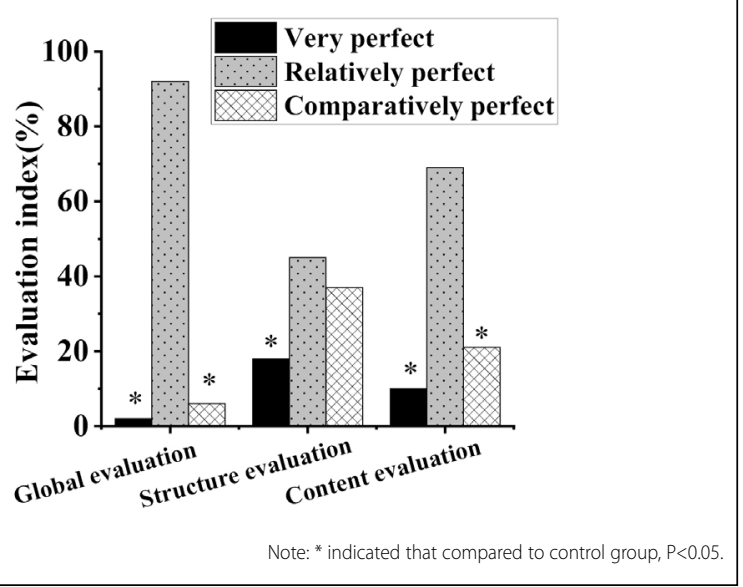

Figure 3. Statistics of validity test results.
Table 5. Comparison of track and field sports forewarning model results with actual results.

\begin{tabular}{c|c|c|c|c}
\hline $\begin{array}{c}\text { Sample } \\
\text { number }\end{array}$ & $\begin{array}{c}\text { Forewarning } \\
\text { model results }\end{array}$ & Actual results & Risk level & $\begin{array}{c}\text { Coach evaluation } \\
\text { results }\end{array}$ \\
\hline 1 & 1.2341 & 1 & Low risk & Valid \\
\hline 2 & 2.1417 & 2 & Medium risk & Valid \\
\hline 3 & 2.5183 & 2 & Medium risk & High risk \\
\hline 4 & 1.5892 & 1 & Low risk & Valid \\
\hline 5 & 2.2547 & 2 & Low risk & Valid \\
\hline 6 & 3.3654 & 3 & High risk & High risk \\
\hline 7 & 1.5474 & 1 & Low risk & Valid \\
\hline 8 & 2.5481 & 2 & Low risk & Valid \\
\hline 9 & 0.9521 & 1 & Low risk & Valid \\
\hline 10 & 1.2547 & 1 & Low risk & Valid \\
\hline
\end{tabular}

\section{DISCUSSION}

In this paper, the different injury factors of athletes are statistically analyzed. The study found that the risk of sports injury caused by athletes' subjective fatigue state was the highest, almost all of them were 3 points. For exercise intensity, the risk value is also kept between 2-3.14

In this work, RBF neural network was integrated into the forewarning model of track and field sportsmen injury. Compared with the actual result quantitative assignment, the relative error was controlled between -0.04-0.04..$^{15}$ According to the coach's evaluation results, the results were consistent at high risk levels, but at medium risk and low risk levels, the RBF neural network motion model was more accurate.

\section{CONCLUSION}

The track and field sports early warning model of RBF neural network is established. Through the sample database test, the field sports mode under the tracking of RBF neural network has achieved good results. It is necessary to expand the sample database in track and field early warning and improve the accuracy of evaluation. All in all, the track and field early warning model based on the RBF neural network can estimate the risk of sports injury to a certain extent, and provide a theoretical basis for the future practical application.

The author declare no potential conflict of interest related to this article

AUTHORS' CONTRIBUTIONS: Heqiong Wen analyzed the different injury factors of athletes, designed the track and field sports early warning model of RBF neural network, and wrote this paper.

\section{REFERENCES}

1. Macdonald B, McAleer S, Kelly S, Chakraverty R, Johnston M, Pollock N. Hamstring rehabilitation in elite track and field athletes: applying the British Athletics Muscle Injury Classification in clinical practice. Br J Sports Med. 2019;53(23):1464-73

2. Zappia MP, Rogers A, Islam ABMMK, Frolov MV. Rbf Activates the Myogenic Transcriptional Program to Promote Skeletal Muscle Differentiation. Cell Rep. 2019;26(3):702-719.e6.

3. El Ansari W, Lovell G. Barriers to exercise in younger and older non-exercising adult women: a cross sectional study in London, United Kingdom. Int J Environ Res Public Health. 2009;6(4):1443-55.

4. Kearney PE, Hayes PR. Excelling at youth level in competitive track and field athletics is not a prerequisite for later success. J Sports Sci. 2018;36(21):2502-9.

5. Zaremski JL, Zeppieri G Jr, Tripp BL. Sport specialization and overuse injuries in adolescent throwing athletes: a narrative review. J Athl Train. 2019;54(10):1030-9.

6. Grobler L, Derman W, Racinais S, Ngai ASH, van de Vliet P. Illness at a Para Athletics Track and Field World Championships under Hot and Humid Ambient Conditions. PM R. 2019;11(9):919-25.

7. Witard OC, Garthe I, Phillips SM. Dietary Protein for Training Adaptation and Body Composition Manipulation in Track and Field Athletes. Int J Sport Nutr Exerc Metab. 2019;29(2):165-74.

8. Lis DM, Kings D, Larson-Meyer DE. Dietary Practices Adopted by Track-and-Field Athletes: Gluten-Free
Low FODMAP, Vegetarian, and Fasting. Int J Sport Nutr Exerc Metab. 2019;29(2):236-45.

9. Peeling P, Castell LM, Derave W, de Hon O, Burke LM. Sports Foods and Dietary Supplements for Optimal Function and Performance Enhancement in Track-and-Field Athletes. Int J Sport Nutr Exerc Metab. 2019;29(2):198-209.

10. Close GL, Sale C, Baar K, Bermon S. Nutrition for the Prevention and Treatment of Injuries in Track and Field Athletes. Int J Sport Nutr Exerc Metab. 2019;29(2):189-97.

11. Li XK, Yan FH, Ma J, Chen ZZ, Wen XY, Cao Y. RBF and NSGA-II based EDM process parameters optimization with multiple constraints. Math Biosci Eng. 2019;16(5):5788-803.

12. Hamby S, Taylor E, Smith A, Mitchell K, Jones L, Newlin C. New measures to assess the social ecology of youth: A mixed-methods study. J Community Psychol. 2019;47(7):1666-81.

13. Ince ML. Supporting learning of practitioners and early career scholars in physical education and sports pedagogy. Sport Educ Soc. 2019;24(6):584-96.

14. Donohue B, Gavrilova E, Strong M, Allen DN. A sport-specific optimization approach to mental wellness for youth in low-income neighborhoods. European Physical Education Review. 2020;26(3):695-712.

15. Vella SA. Mental health and organized youth sport. Kinesiology Review. 2019;8(3):229-36 